\title{
Buccal Fat Pad: Report of 24 Cases and Literature Review of 1,635 Cases of Oral Defect Reconstruction
}

\author{
Giuditta Mannellia ${ }^{a}$ Francesco Arcuri ${ }^{b}$ Lara Valentina Comini ${ }^{a}$ \\ Domenico Valente $^{b}$ Giuseppe Spinelli ${ }^{b}$ \\ ${ }^{a}$ Clinic of Otorhinolaryngology Head and Neck Surgery, Department of Surgery and \\ Translational Medicine, University of Florence, Azienda Ospedaliero-Universitaria Careggi, \\ Florence, Italy; ${ }^{b}$ Maxillo-Facial Surgery Unit, Neurosensorial Department, Azienda \\ Ospedaliero-Universitaria Careggi, Florence, Italy
}

\section{Keywords}

Buccal fat pad · Bichat flap - Oral defect reconstruction - Literature review

\begin{abstract}
Objective: The buccal fat pad (BFP) has been progressively introduced into clinical practice for oral defect reconstruction. This study describes our experience with this technique and compares indications in the literature and outcomes. Methods: We prospectively enrolled 24 patients presenting oral surgical defects and treated between January 2012 and January 2015 at our institution. They all were eligible for BFP defect reconstruction. A comprehensive literature review was performed from 1977 onwards and surgical indications and results were compared. Results: All 24 BFP procedures showed excellent recovery and uneventful followup. Literature review confirmed a global success rate of $96.2 \%$ for a reported number of 1,635 patients with multiple surgical indications. BFP showed very low morbidity and failure rates in accordance with the outcomes reported in the literature, and the high patient compliance together with the easy harvesting of this surgical technique make it a good reconstructive option in cases of small-to-medium size oral defects in patients with a high rate of comorbidities or as salvage/second option. Conclusion: The BFP is worthy of consideration for the reconstruction of selected mouth defects, due to its easy mobilization, excellent blood supply, and minimal donor-site morbidity, where shape and size represent its main limitations, and a defect's location influences its pliability.


Mannelli et al.: Indications and Outcomes

\section{Introduction}

The buccal fat pad (BFP) is a mass of fatty tissue, distinct from subcutaneous fat, situated in the masticatory space close to the Stenone's duct. It extends along the anterior border of the masseter, deeply between the buccinator muscle medially and the mandible laterally, descending to the retromolar region. It consists of fat (approx. $10 \mathrm{~mL}$ in volume) covered by a fascial envelope [1]. The BFP was first described as surgical option for oral reconstruction by Egyedi [2] in 1977, but no studies on its vessel supply were conducted until 1986, when Tideman et al. [3] published a detailed description of its anatomy and operative technique. During recent years, an increasing number of clinical studies on a progressively larger number of case series, have stated the utility and versatility of the BFP for the reconstruction of smallto-medium-sized oral defects, by counting various applications of BFP including the closure of surgical defects following the excision of malignant or benign tumors, the repair of surgical defects following the excision of leukoplakia and submucous fibrosis, the closure of primary and secondary palatal clefts, the coverage of maxillary and mandibular bone grafts, and the lining of the sinus surface of maxillary sinus bone grafts in the sinus lift procedure for maxillary augmentation, temporomandibular joint (TMJ) arthroplasty, elongation of the soft palate, vocal cord augmentation, osteonecrosis (ON) of the jaw, and root coverage [4-6].

Different scenarios for the application of the BFP are reported in this article, together with an accurate and updated review of the whole published literature supporting the use of the BFP, in order to better emphasize its success rate and support the indication of the technique for the reconstruction of different oral defects. Our outcomes were reported as well, to show their agreement with the results in the literature and to confirm the universal applicability of the BFP.

\section{Patients and Methods}

\section{Study Population}

In the period 2012-2015, a total of 24 patients were prospectively enrolled and surgically treated at the Maxillo-Facial Unit, Azienda Ospedaliero-Universitaria Careggi, Florence. Biopsy-proven oral malignancies were classified according to American Joint Committee on Cancer (AJCC, ed. 7) staging [7] and the WHO classification (2005) [8]. This study was approved by the Hospital Institutional Review Board, all participants signed an informed consent agreement, and the study is in accordance with the Declaration of Helsinki. Patients who did not give their consent were excluded, but any previous treatment for head and neck pathology did not represent a contraindication for enrolment.

Characteristics regarding patients, oral disease, and treatment were extracted from each patient's records (Table 1). There were 10 men and 14 women. Their age ranged between 39 and 88 years (median 67.5 years, mean $66.46 \pm 14.49$ SD). Fourteen underwent horizontal maxillectomy class 2 according to the classification used by Brown et al. [9], and their oral defect was classified as type II according to Aramany [10]. Five patients underwent transoral resection of retromolar lesions, 3 presented cheek lesions, and 2 had mandible localization of disease. Four patients (16.6\%) had previous head and neck cancer treatments (3 had radiotherapy and 1 had surgery), and they experienced second primary tumors, 2 squamous-cell carcinomas (SCCs) and 1 mucoepidermoid (ME) cancer. Histological final report confirmed that we treated 12 cases of oral SCC, 3 of adenoid cystic carcinoma (ACC), 6 of ME cancer, and 3 of ON. Oral defects presented with a median size of $30.5 \mathrm{~mm}$, a maximum diameter of $18-50 \mathrm{~mm}$, and they were all repaired by the BFP technique. All specimens showed clear resection margins at the final pathological report.

The senior surgeon (G.S.) performed every surgical procedure, and after each tumor resection, he harvested the BFP by making an intraoral blunt dissection anterior and medial to the coronoid process, carefully spreading the fascia and the fat pad. Care was always taken to tease the pedicle to the maximum extent of its supporting vascular plexus and stroma, and periosteal tags were planned in advance to suture the most advanced portion of the fat graft (Fig. 1).

Flap outcomes were evaluated during hospital stay and clinical follow-up. Fair reconstruction outcomes included the epithelialization of the flap, together with the achievement of a complete closure of the oral 
Mannelli et al.: Indications and Outcomes

Table 1. Summary of clinical details of the 24 patients

\begin{tabular}{|c|c|c|c|c|c|c|c|}
\hline $\begin{array}{l}\text { Patient } \\
\text { No. }\end{array}$ & $\begin{array}{l}\text { Age, } \\
\text { years }\end{array}$ & Gender & $\begin{array}{l}\text { Previous head and } \\
\text { neck treatment }\end{array}$ & Oral defect location & Histology & $\begin{array}{l}\text { Defect size, } \\
\mathrm{mm}\end{array}$ & Complications \\
\hline 1 & 64 & M & No & Maxilla & ACC & 44 & No \\
\hline 2 & 87 & M & Yes (RT) & Maxilla & $\mathrm{ON}$ & 38 & No \\
\hline 3 & 76 & $\mathrm{~F}$ & No & Maxilla & $\mathrm{ON}$ & 49 & Yes \\
\hline 4 & 47 & M & No (RT) & Maxilla & $\mathrm{ME}$ & 22 & No \\
\hline 5 & 86 & $\mathrm{~F}$ & No & Maxilla & $\mathrm{ME}$ & 36 & No \\
\hline 6 & 58 & M & No & Maxilla & SCC & 22 & No \\
\hline 7 & 67 & $\mathrm{~F}$ & No & Maxilla & $\mathrm{ME}$ & 30 & No \\
\hline 8 & 64 & $\mathrm{~F}$ & Yes (S) & Maxilla & SCC & 27 & No \\
\hline 9 & 84 & $\mathrm{~F}$ & No & Maxilla & ME & 35 & No \\
\hline 10 & 39 & M & No & Maxilla & ACC & 37 & No \\
\hline 11 & 48 & $\mathrm{~F}$ & No & Maxilla & ACC & 30 & No \\
\hline 12 & 68 & M & No & Maxilla & $\mathrm{ME}$ & 28 & No \\
\hline 13 & 71 & $\mathrm{~F}$ & No & Maxilla & SCC & 31 & No \\
\hline 14 & 88 & $\mathrm{~F}$ & No & Maxilla & SCC & 40 & No \\
\hline 15 & 71 & M & No & Maxilla & SCC & 34 & No \\
\hline 16 & 80 & $\mathrm{~F}$ & No & Retromolar trigone & SCC & 26 & No \\
\hline 17 & 68 & $\mathrm{~F}$ & No & Retromolar trigone & $\mathrm{ME}$ & 30 & No \\
\hline 18 & 66 & M & Yes (RT) & Retromolar trigone & SCC & 34 & No \\
\hline 19 & 59 & $\mathrm{~F}$ & No & Retromolar trigone & SCC & 40 & No \\
\hline 20 & 41 & M & No & Cheek & SCC & 24 & No \\
\hline 21 & 53 & $\mathrm{~F}$ & No & Cheek & SCC & 18 & No \\
\hline 22 & 70 & M & No & Cheek & SCC & 43 & No \\
\hline 23 & 55 & M & No & Mandible & $\mathrm{ON}$ & 25 & No \\
\hline 24 & 85 & $\mathrm{~F}$ & No & Mandible & SCC & 23 & No \\
\hline
\end{tabular}

M, male; F, female; RT, radiotherapy; S, surgery; ME, mucoepidermoid carcinoma; ACC, adenoidcystic carcinoma; OSCC, oral squamous cell carcinoma; ON, ostenecrosis.

Fig. 1. Clinical case of a 66-yearold woman with a previous history of complementary radiotherapy treatment for left parotid cancer when she was 48 years old, now affected by an SCC of her left superior retromolar trigone (a, black arrow); she underwent transoral cancer resection and the oral defect was completely repaired by BFP (b).
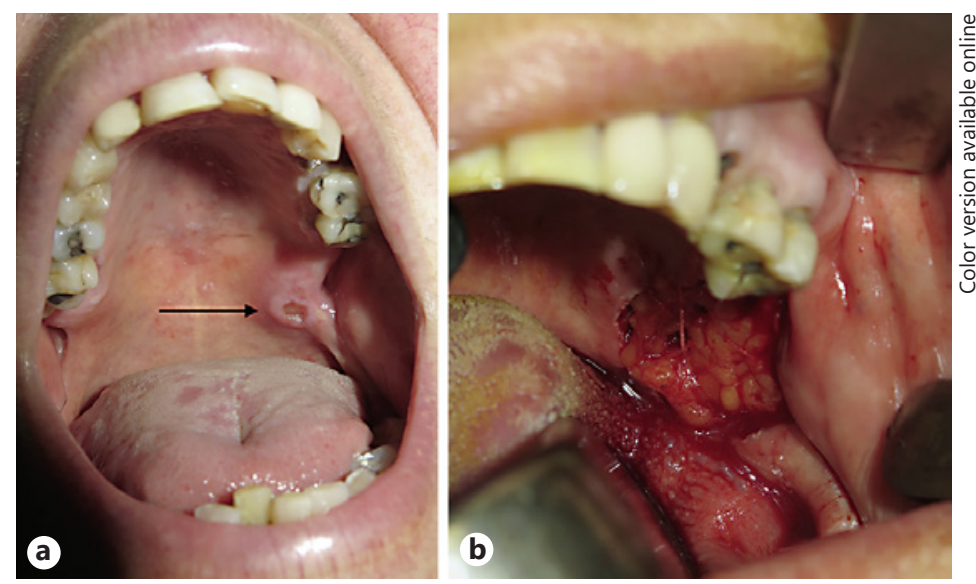

defect at 1, 3, and 6 months, and to 2 years after the operation. Complications included the onset of partial or complete flap necrosis, postoperative local infection, excessive scarring, oronasal communication, or fistula. In addition, facial contour deficiency was assessed preoperatively and postoperatively from photographs, and good functional recovery was supposed to ensure postoperative labial commissure continence and a preserved mouth opening. Only 1 patient out of 24 (4\%) experienced flap dehiscence requiring a second operation, and the defect was reconstructed by means of a temporalis myofascial pedicle flap. 

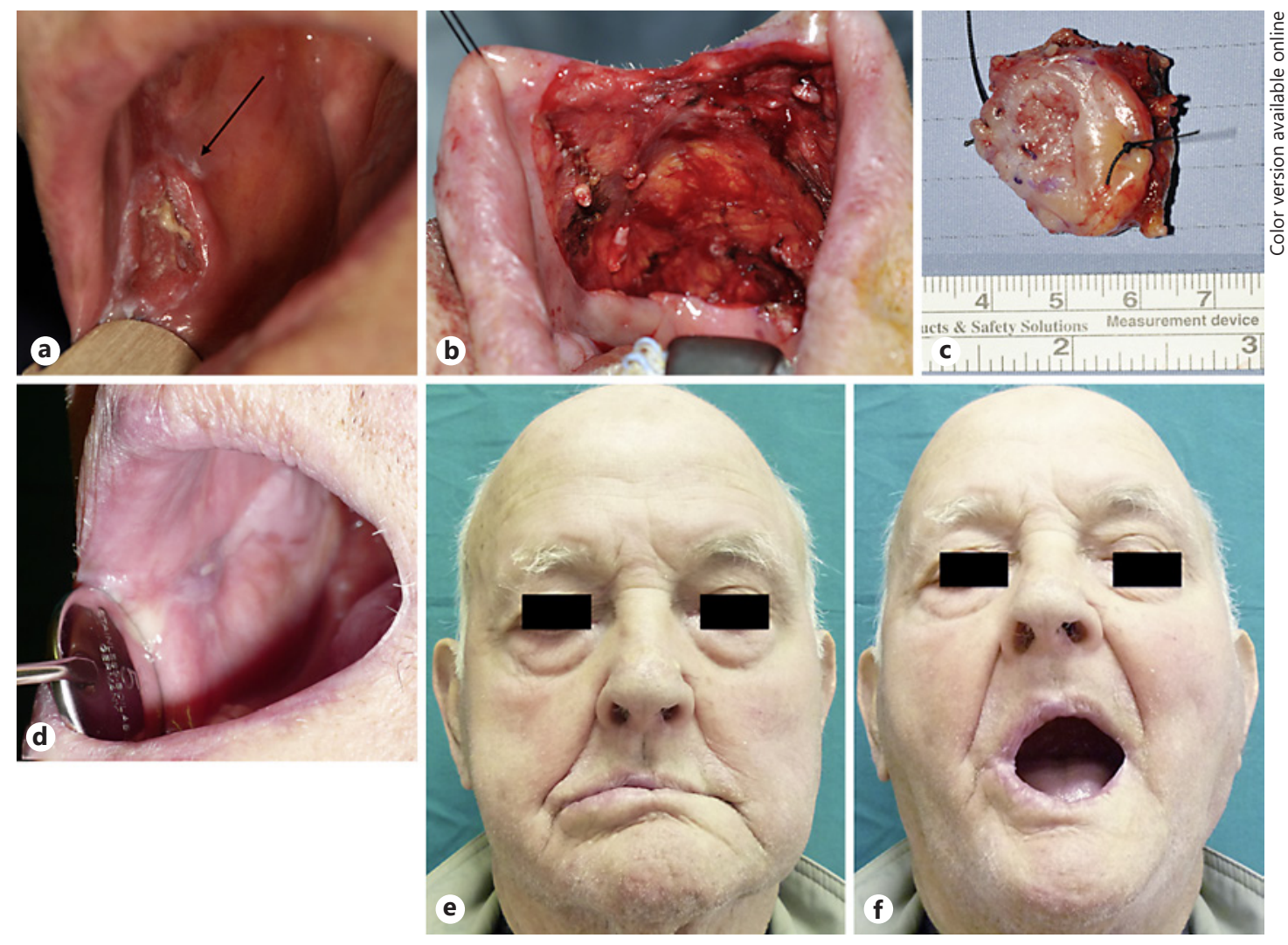

Fig. 2. Clinical case of a 70-year-old man presenting an SCC of his right cheek mucosa with a labial paracommissural extension (a, black arrow); he underwent tumor transoral resection with a following oral defect with a maximum diameter of $43 \mathrm{~mm}$ (b). c The surgical specimen measured about $3 \mathrm{~cm}$ in maximum dimension. BFP was harvested and complete recovery was seen 4 weeks after the operation (d), with a conservative facial symmetry (e) and complete conservative mouth opening function (f).

Fig. 3. Clinical case of a 76-yearold woman, with a previous history of bisphosphonate treatment after breast cancer, who underwent a right maxillectomy with a following oral defect of $49 \mathrm{~mm}$ maximum diameter reconstructed by BFP (a); she healed completely in 6 weeks (b), without complaining of any cosmetic or functional impairment (c).
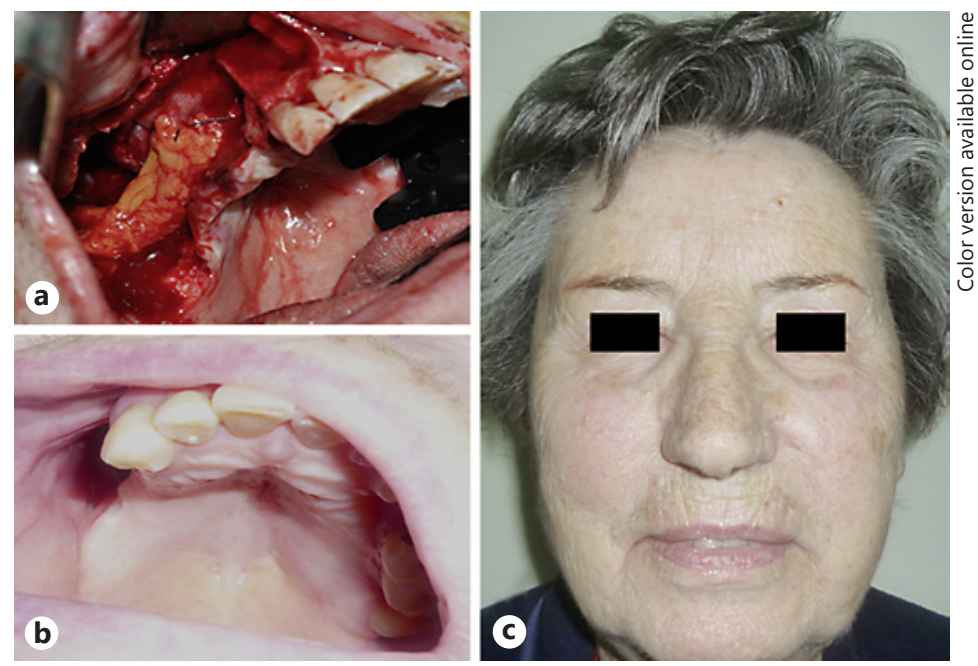
Fig. 4. Clinical case of a 66-yearold woman, affected by a mucoepidermoid cancer of her right retromolar trigone region, who underwent a transoral tumor resection and the oral defect presented a maximum diameter of $3 \mathrm{~cm}$ repaired by BFP (a); the final surgical specimen measured about $2.5 \times 2 \times 0.7 \mathrm{~cm}$ (b). c, d She showed a completely epithelialized wound and oral-defect closure (black arrow) after the first postoperative month, with conservative excellent mouth opening.
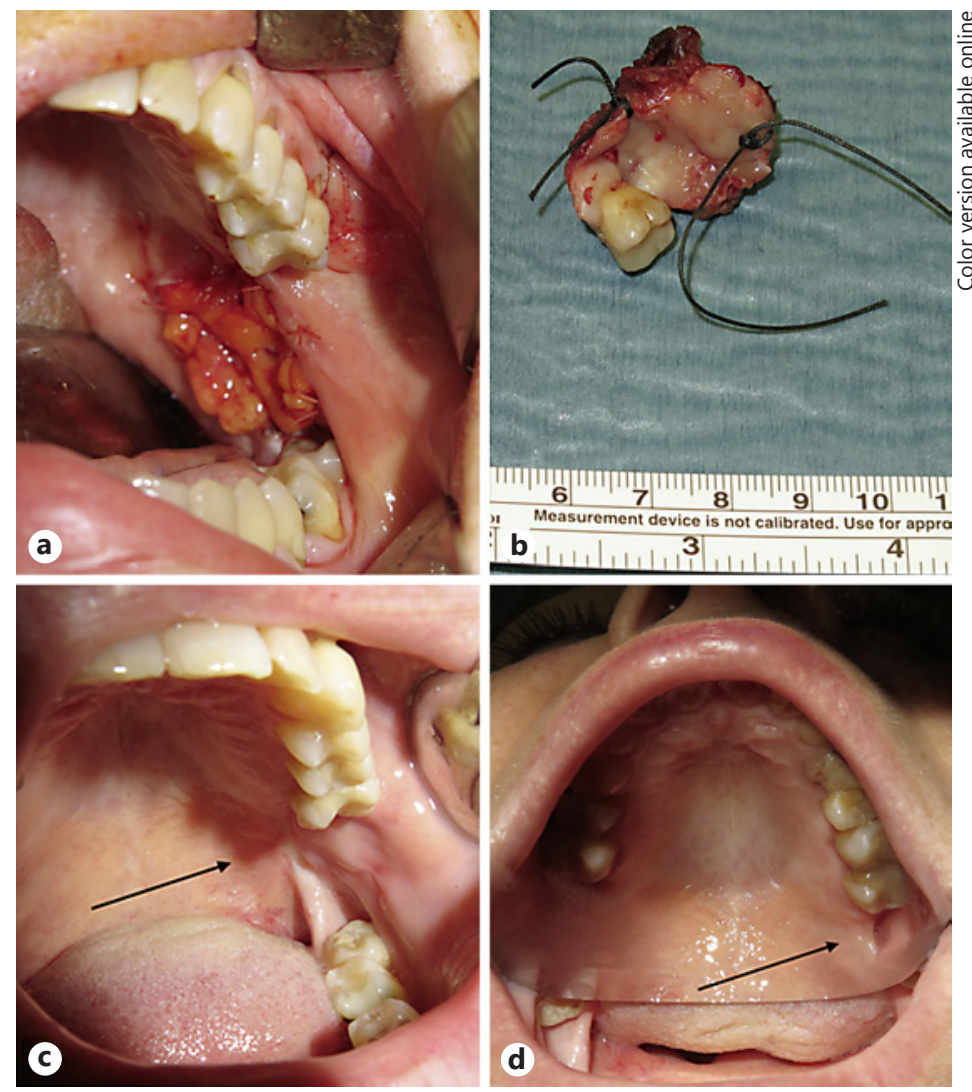

\section{Literature Review Analysis}

A computerized literature search was conducted for articles published from January 1977 to December 2017 on BFP and its applications. MeSH terms used in the search were: buccal pad of fat and its application, buccal fat pad, and Bichat's; "And" was used as a Boolean operator to combine and narrow the search. A total of 94 articles were selected for the review based on the criteria for the study, and included case reports, case series, retrospective case series, randomized controlled trials, comparative studies, technical notes, and abstracts (not included in the review). Clinical case series were found to be most informative regarding correlation between various uses and complications and were thus included for completion of the discussion.

\section{Statistical Analysis}

Categorical variables were calculated in terms of frequencies and percentages for all patients included in the study. The Kruskal-Wallis test was used for statistical comparisons by STATA v12.1 (StataCorp. 2011. Stata Statistical Software: Release 12. College Station, TX, USA), and $p<0.05$ was considered statistically significant.

\section{Results}

In our case series, all the $24 \mathrm{BFP}$ epithelialized completely in 1 month, and within the first 2 months after the operation the fat tissue was completely covered by healthy-looking oral mucosa. No early or late postoperative complications were observed, and normal mouth functions and opening were conserved in all patients (Fig. 2-4).

Only 1 patient had experienced a partial dehiscence at the 1-month follow-up, so he received a second surgical operation and the defect was repaired by a temporalis muscle 
Mannelli et al.: Indications and Outcomes

Table 2. Summary of historical review of buccal fat pad use for the reconstruction of oral defects

\begin{tabular}{lccl}
\hline Indications for BFP & Patients, $n$ & Complications, $n$ & References \\
\hline Oroantral fistula & 542 & 15 & $14-36$ \\
Cleft palate, lip, and alveolus & 223 & 2 & $35,38-50$ \\
Osteonecrosis of the jaw & 50 & 5 & $35,52-58$ \\
Cyst or tumor & 363 & 38 & $2-4,13,20,27,35,59-75$ \\
Oral submucous fibrosis & 108 & 1 & $76-81$ \\
Tempomandibular arthroplasty & 76 & 0 & $82-88$ \\
Skull base repair & 188 & 0 & 90 \\
Other & 85 & 0 & $89,91-98$ \\
Total & 1,635 & 61 & (see text for indications) \\
\hline
\end{tabular}

homolateral flap. None of the 24 patients underwent postoperative radiotherapy and all of them still presented a regular and disease-free follow-up in June 2017.

Literature review selected a global number of 94 articles: 80 clinical articles, 8 anatomical studies, 3 reviews, 1 experimental study, and 2 discursive articles. Only 12 clinical articles were published prior to 1999; since 2000, surgical applications of the BFP increased in numbers and indications.

Table 2 shows historical review of BFP use for the reconstruction of oral defects, where surgical indications for BFP application, related complications, and the references are reported for 1,635 patients.

The rate of overall complications was around 3.8\% $(n=61)$, and this value was much lower than that published by Rapidis et al. [4] in 2000 (16.4\%). In 2010, Singh et al. [5], and then Kim et al. in 2017 [11], reported a decrease in the incidence of complications and a corresponding reduction in indications for salvage surgery (of $<1 \%$ of cases), with an evident extension of BFP surgical applications. The most common complications described were represented by flap partial necrosis, local infection, excessive local scarring especially in cancer patients undergoing adjuvant radiotherapy treatment, late wound dehiscence, and oroantral/oronasal fistula, where patients' comorbidities and wrong indications were the main influencing factors.

\section{Discussion}

Intraoral soft tissue defects can be caused by several different diseases or complications [11], and donor-site morbidity with addition scarring, together with the longer operation time discourage the use of vascularized flaps especially in for the reconstruction of small-tomedium-sized oral defects and in patients at a high risk of flap failure.

After an accurate literature review, we can assume that the BFP is a versatile surgical reconstructive option in terms of its location and application, thanks to the easy, fast, and safe harvesting technique. In fact, the BFP, if properly dissected and mobilized, is a thin and pliable flap which can provide a long and wide-based pedicle whose maximum diameter could reach up to $7 \times 4 \times 3 \mathrm{~cm}$ of tissue transferred [4]. Its rich inflow and outflow is facilitated by the small side vessels of the facial artery, the buccal and deep temporal branches of the maxillary artery, and the transverse facial branches of the superficial temporal artery. For this reason, the BFP can be considered as a pedicled graft with an axial pattern $[5,12]$. The epithelialization process lasts about 6 weeks and it seems that covering stratified squamous epithelium and deep fibrous tissue complete its healing, 
regardless of the extent of graft coverage with oral mucosa [13-17]. It has been put to many uses $[4,5]$ and its long-term success has been attributed to its rich vascular supply and lower donor-site morbidity.

Here, we went through the different BFP applications by listing the reference articles as well as the outcomes and contraindications associated with the technique. Oroantral fistula after extraction, especially in patients previously treated by buccal advancement flap or presenting with damaged gingiva, was the first and most analyzed BFP indication since the 1970 s, and the literature cites optimal results, with an overall success rate of $97.2 \%$, in the reported 542 patients [14-36]. The only contraindication to BFP use was in cases of bone replacementand planned implant installation. In addition, the state of the teeth was considered to influence the selection of fat pad pedicle flap shape and position.

Cleft lip and palate represent another type of oral congenital defect suitable for BFP application. The success rate is influenced by many factors, and the incidence of postoperative palatal fistula is reported to be in the range of 4.6-12.5\%, with ischemic damage and wound contracture being the main causes of complications [37]. Despite the absence of comparative studies, a global case series involving 223 patients showed the capacity of the BFP technique to prevent palatal fistula and cover the raw bone surface after sealing the palatal flap. It showed good results also as salvage option for secondary palatal defects with a comprehensive failure rate of $0.9 \%$ with no velopharyngeal insufficiency claims, no impairment in the function and growth of the palate observed, and no aesthetic deformity reported [35, 38-50]. A contraindication to BFP use exists in cases of anterior palatal defects, although Pinto and Debnath [51] have described a surgical technique using BFP for lining a nasal defect during a releasing pushback palatoplasty.

A total of 7 papers proposed the BFP as a possible surgical option in case of small ON of the jaws, but here, size, location, and advanced disease stage usually direct therapy towards more aggressive surgical procedures, microvascular surgery included [35, 52-58].

Oral cancer patients represent a big chapter of BFP use, which has increasingly found application since 1977. A total of 25 papers were included in this review, where 50 patients were treated after benign tumor resection and the remaining 313 were affected by malignant tumors $[2-4,13,20,27,35,59-75]$. Despite the high success rate recorded (89.5\%), it was commonly believed that BFP should be used as a salvage option in cancer patients, due to the possible incidence of scar contracture following cheek depression after adjuvant treatment [4]. We can affirm, based both on our results and the recent literature findings [75], that previous head and neck radiation treatment does not represent an absolute contraindication to BFP use. Regarding defect size, oral defects exceeding $4 \times 4 \times 3 \mathrm{~cm}$ showed the highest failure rate in cancer patients, thus discouraging the use of this flap as first option for these patients [53]. The potential complications found were minimal; hematoma, infection $(0.6 \%)$, facial nerve injury, partial necrosis (7.9\%), and excessive scar formation (5.4\%) were reported as the most common [73].

One hundred and eight cases of oral submucous fibrosis have been described so far with only 1 complication being found, i.e., a precancerous lesion of the oral mucosa whose major feature is a mouth-opening limitation. Although several studies proposed BFP application in this disease as favorable option, there is no robust evidence of evaluation criteria such as long-term stability of mouth function [76-81].

Other application for the BFP includes TMJ reconstruction, where a minimal gap of 6-7 $\mathrm{mm}$ is recommended for the arthroplasty [82-88], upper-lip profile improvement after maxillary advancement surgery by Le Fort I osteotomy [89], skull-base defect repair after tumor resection [90], prevention of Frey syndrome after parotid surgery [91, 92], repair of the maxillary sinus membrane after dental implant [93, 94], vocal cord augmentation [95], and reconstruction of facial contour deformity even after facial trauma [96-98]. 
All of the abovementioned indications are influenced by the size and oral location of a defect. The shape of the paddle could be rounded or rectangular, with a minimum and maximum diameter ranging from 18 to $30 \mathrm{~mm}$. In fact, defects $>4 \mathrm{~cm}$ in diameter and palatal defects both involve a high probability of wound dehiscence and partial necrosis during early follow-up, due to their ends stretching. On the other hand, lateral maxillary, cheek, or labial commissure defects up to $7 \mathrm{~cm}$ in size can be successfully reconstructed. The location of the BFP main body deeply along the posterior maxilla and the upper fibers of the buccinator muscle explains its good results in covering posterior defects, even if the presence of posterior teeth could obviously limit its anchorage $[4,5]$.

Morbidity of the donor site is low; however, in patients with a small BFP volume, previous local treatment, maxillary hypoplasia, or thin cheeks, other techniques should be considered for the management of the donor site. An alternative for palatal closure may be tongue flaps, but this involves a 2-stage procedure. In accordance with the literature review, we believe that the BFP is preferable for soft-palate and retromolar reconstruction than the buccinator musculomucosal flap [99] or the inferior-based facial-artery musculomucosal flap [100]. It can also be used to reconstruct T2 tumor defects because it is expandable.

We can conclude that the main advantages of BFP are the ease of harvesting, and the simplicity, versatility, and low rate of complications that attend a quick surgical technique. The operation can be performed with 1 incision, affecting neither the appearance nor the function of the area. It is evident from the literature that surgeons have been searching progressively for simpler reconstructive techniques, that would be equally effective but involve a lower rate of complications and faster recovery. BFP does have its limitations but, with good patient selection, it nevertheless remains a good reconstructive option for smallto-medium-sized oral defects.

The limitation of size must be known to ensure a successful outcome. In addition, a recent publication showed promising stem-like potentials of BFP adipose cells as a possible source for bone regeneration in cleft-palate patients; this might herald new and future perspectives for the use of this tissue [101].

\section{Disclosure Statement}

All authors assure that this paper has not been published and is not under approval by other journals or editors, and that there are no conflicts of interest, financial or otherwise.

\section{Author Contributions}

Each author has participated actively in designing and writing this article; Giuditta Mannelli was the main writer and she assisted in conception of the study and reviewed it critically for important intellectual content. Giuseppe Spinelli was the main creator of the work, and he is the senior surgeon who performed all the surgical procedures and gave final approval for this version of the paper. Francesco Arcuri, Lara Valentina Comini, and Domenico Valente made an important contribution due to their good knowledge in statistics and their collection of each patients' data. 
Mannelli et al.: Indications and Outcomes

\section{References}

1 Arce K. Buccal fat pad in maxillary reconstruction. Atlas Oral Maxillofac Surg Clin North Am. 2007 Mar;15(1): 23-32.

2 Egyedi P. Utilization of the buccal fat pad for closure of oro-antral and/or oro-nasal communications. J Maxillofac Surg. 1977 Nov;5(4):241-4.

3 Tideman H, Bosanquet A, Scott J. Use of the buccal fat pad as a pedicled graft. J Oral Maxillofac Surg. 1986 Jun; 44(6):435-40.

4 Rapidis AD, Alexandridis CA, Eleftheriadis E, Angelopoulos AP. The use of the buccal fat pad for reconstruction of oral defects: review of the literature and report of 15 cases. J Oral Maxillofac Surg. 2000 Feb;58(2):158-63.

5 Singh J, Prasad K, Lalitha RM, et al. Buccal fat pad and its applications in oral and maxillofacial surgery: a review of published literature (February). Oral Surg Oral Med Oral Pathol Oral Radiol Endod. 2010;110:698.

6 Gröbe A, Eichhorn W, Hanken H, Precht C, Schmelzle R, Heiland M, et al. The use of buccal fat pad (BFP) as a pedicled graft in cleft palate surgery. Int J Oral Maxillofac Surg. 2011 Jul;40(7):685-9.

7 Edge SB, Compton CC. The American Joint Committee on Cancer: the 7th edition of the AJCC cancer staging manual and the future of TNM. Ann Surg Oncol 2010 Jun;17(6):1471-4.

8 Barnes L, Eveson JW, Reichart P, Sidransky D. WHO Classification Head and Neck Tumors. Lyon: IARC; 2005.

9 Brown JS, Rogers SN, McNally DN, Boyle M. A modified classification for the maxillectomy defect. Head Neck. 2000 Jan;22(1):17-26.

10 Aramany MA. Basic principles of obturator design for partially edentulous patients. Part I: classification. J Prosthet Dent. 1978 Nov;40(5):554-7.

11 Kim MK, Han W, Kim SG. The use of the buccal fat pad flap for oral reconstruction. Maxillofac Plast Reconstr Surg. 2017 Feb;39(1):5.

12 Zhang HM, Yan YP, Qi KM, Wang JQ, Liu ZF. Anatomical structure of the buccal fat pad and its clinical adaptations. Plast Reconstr Surg. 2002 Jun;109(7):2509-18.

13 Samman N, Cheung LK, Tideman H. The buccal fat pad in oral reconstruction. Int J Oral Maxillofac Surg. 1993 Feb;22(1):2-6.

14 Baumann A, Ewers R. Application of the buccal fat pad in oral reconstruction. J Oral Maxillofac Surg. 2000 Apr; 58(4):389-92.

15 Hanazawa Y, Itoh K, Mabashi T, Sato K. Closure of oroantral communications using a pedicled buccal fat pad graft. J Oral Maxillofac Surg. 1995 Jul;53(7):771-5.

16 Poeschl PW, Baumann A, Russmueller G, Poeschl E, Klug C, Ewers R. Closure of oroantral communications with Bichat's buccal fat pad. J Oral Maxillofac Surg. 2009 Jul;67(7):1460-6.

17 Dolanmaz D, Tuz H, Bayraktar S, Metin M, Erdem E, Baykul T. Use of pedicled buccal fat pad in the closure of oroantral communication: analysis of 75 cases. Quintessence Int. 2004 Mar;35(3):241-6.

18 Daif ET. Long-term effectiveness of the pedicled buccal fat pad in the closure of a large oroantral fistula. J Oral Maxillofac Surg. 2016 Sep;74(9):1718-22.

19 Adams T, Taub D, Rosen M. Repair of oroantral communications by use of a combined surgical approach: functional endoscopic surgery and buccal advancement flap/buccal fat pad graft. J Oral Maxillofac Surg. 2015 Aug; 73(8):1452-6.

20 Alkan A, Dolanmaz D, Uzun E, Erdem E. The reconstruction of oral defects with buccal fat pad. Swiss Med Wkly. 2003 Aug;133(33-34):465-70.

21 Abad-Gallegos M, Figueiredo R, Rodríguez-Baeza A, Gay-Escoda C. Use of Bichat's buccal fat pad for the sealing of orosinusal communications. A presentation of 8 cases. Med Oral Patol Oral Cir Bucal.2011 Mar;16(2):e215-9.

22 Nezafati S, Vafaii A, Ghojazadeh M. Comparison of pedicled buccal fat pad flap with buccal flap for closure of oro-antral communication. Int J Oral Maxillofac Surg. 2012 May;41(5):624-8.

23 Martín-Granizo R, Naval L, Costas A, Goizueta C, Rodriguez F, Monje F, et al. Use of buccal fat pad to repair intraoral defects: review of 30 cases. Br J Oral Maxillofac Surg. 1997 Apr;35(2):81-4.

24 Alonso-González R, Peñarrocha-Diago M, Peñarrocha-Oltra D, Aloy-Prósper A, Camacho-Alonso F, Peñarrocha-Diago M. Closure of oroantral communications with Bichat's buccal fat pad. Level of patient satisfaction. J Clin Exp Dent. 2015 Feb;7(1):e28-33.

25 Stajcić Z. The buccal fat pad in the closure of oro-antral communications: a study of 56 cases. J Craniomaxillofac Surg. 1992 Jul;20(5):193-7.

26 Jain MK, Ramesh C, Sankar K, Lokesh Babu KT. Pedicled buccal fat pad in the management of oroantral fistula: a clinical study of 15 cases. Int J Oral Maxillofac Surg. 2012 Aug;41(8):1025-9.

27 Chaudhary B, Gong Z, Lin Z, Abbas K, Ling B, Liu H. Reconstruction of intraoral maxillary defect with buccal fat pad. J Craniofac Surg. 2014 Nov;25(6):2174-7.

28 Sharma CB, Sharma P, Bali R, et al. Use of single layered buccal fat pad in the closure of maxillary sinus defects. J Maxillofac Oral Surg. 2005;4:15.

29 Abuabara A, Cortez AL, Passeri LA, de Moraes M, Moreira RW. Evaluation of different treatments for oroantral/ oronasal communications: experience of 112 cases. Int J Oral Maxillofac Surg. 2006 Feb;35(2):155-8.

30 Haraji A, Zare R. The use of buccal fat pad for oro-antral communications closure.J Mashhad Dent Sch Mashhad Univ Med Sci. 2007;31:9-11.

31 Adeyemo WL, Ogunlewe MO, Ladeinde AL, James O. Closure of oro-antral fistula with pedicled buccal fat pad. A case report and review of literature. African J Oral Health. 2004;1(1):42-46. 
Mannelli et al.: Indications and Outcomes

32 de Moraes EJ. Closure of oroantral communication with buccal fat pad flap in zygomatic implant surgery: a case report. Int J Oral Maxillofac Implants. 2008 Jan-Feb;23(1):143-6.

33 Allais M, Maurette PE, Cortez AL, Filho JR, Mazzonetto R. The buccal fat pad graft in the closure of oroantral communications. Rev Bras Otorrinolaringol (Engl Ed). 2008 Sep-Oct;74(5):799.

34 Junior JS, Keim FS, Kreibich MS. Closure of oroantral communication using buccal fat pad graft: case report. Int Arch Otorhinolaryngol. 2008;12:450.

35 Habib AM, Medra A. The Feasibility of Buccal Fat Pad Flap in Oral Reconstruction Based on Clinical Experience in a Governmental Hospital, Alexandria, Egypt. Cleft Palate Craniofac J. 2016 Nov;53(6):657-63.

36 Horowitz G, Koren I, Carmel NN, Balaban S, Abu-Ghanem S, Fliss DM, et al. One stage combined endoscopic and per-oral buccal fat pad approach for large oro-antral-fistula closure with secondary chronic maxillary sinusitis. Eur Arch Otorhinolaryngol. 2016 Apr;273(4):905-9.

37 Musgrave RH, Bremner JC. Complications of cleft palate surgery. Plast Reconstr Surg Transplant Bull. 1960 Aug;26(2):180-9.

38 Ashtiani AK, Bohluli B, Kalantar Motamedi MH, Fatemi MJ, Moharamnejad N. Effectiveness of buccal fat in closing residual midpalatal and posterior palatal fistulas in patients previously treated for clefts. J Oral Maxillofac Surg. 2011 Nov;69(11):e416-9.

39 Ashtiani AK, Fatemi MJ, Pooli AH, Habibi M. Closure of palatal fistula with buccal fat pad flap. Int J Oral Maxillofac Surg. 2011 Mar;40(3):250-4.

40 Zhang Q, Li L, Tan W, Chen L, Gao N, Bao C. Application of unilateral pedicled buccal fat pad for nasal membrane closure in the bilateral complete cleft palate. J Oral Maxillofac Surg. 2010 Aug;68(8):2029-32.

41 Levi B, Kasten SJ, Buchman SR. Utilization of the buccal fat pad flap for congenital cleft palate repair. Plast Reconstr Surg. 2009 Mar;123(3):1018-21.

42 Gröbe A, Eichhorn W, Hanken H, Precht C, Schmelzle R, Heiland M, et al. The use of buccal fat pad (BFP) as a pedicled graft in cleft palate surgery. Int J Oral Maxillofac Surg. 2011 Jul;40(7):685-9.

43 De Riu G, Meloni SM, Bozzo C, Meloni F, Tullio A. A double buccal fat pad flap for middle palate defect closurea new technique for palate closure. Int J Oral Maxillofac Surg. 2006 Nov;35(11):1057-9.

44 Pappachan B, Vasant R. Application of bilateral pedicled buccal fat pad in wide primary cleft palate. Br J Oral Maxillofac Surg. 2008 Jun; 46(4):310-2.

45 Bennett KG, Thurston TE, Vercler CJ, Kasten SJ, Buchman SR. Harvesting the Buccal Fat Pad Does Not Result in Aesthetic Deformity in Cleft Patients: A Retrospective Analysis. Plast Reconstr Surg. 2017 Aug;140(2): 362-8.

46 Zhang M, Zhang X, Zheng C. Application of buccal fat pads in pack palate relaxing incisions on maxillary growth: a clinical study. Int J Clin Exp Med. 2015 Feb;8(2):2689-92.

47 de Castro CH, de Souza LN, Fernandes Santos Melo M. Use of the buccal fat pad as free graft for closure of oronasal fistula in a cleft palate patient. J Craniofac Surg. 2015 Jan;26(1):e14-6.

48 Tuli P, Parashar A, Nanda V, Sharma RK. Delayed buccal fat pad herniation: an unusual complication of buccal flap in cleft surgery. Indian J Plast Surg. 2009 Jan-Jun;42(1):104-5.

49 Kim YK. The use of a pedicled buccal fat pad graft for bone coverage in primary palatorrhaphy: a case report. J Oral Maxillofac Surg. 2001 Dec;59(12):1499-501.

50 Hudson JW, Anderson JG, Russell RM Jr, Anderson N, Chambers K. Use of pedicled fat pad graft as an adjunct in the reconstruction of palatal cleft defects. Oral Surg Oral Med Oral Pathol Oral Radiol Endod. 1995 Jul;80(1): 24-7.

51 Pinto PX, Debnath S. Use of pedicled graft of buccal fat pad to line a nasal defect in releasing pushback palatoplasty. Br J Oral Maxillofac Surg. 2007 Apr;45(3):249-50.

52 Melville JC, Tursun R, Shum JW, Young S, Hanna IA, Marx RE. A technique for the treatment of oral-antral fistulas resulting from medication-related osteonecrosis of the maxilla: the combined buccal fat pad flap and radical sinusotomy. Oral Surg Oral Med Oral Pathol Oral Radiol. 2016 Sep;122(3):287-91.

53 Nabil S, Ramli R. The use of buccal fat pad flap in the treatment of osteoradionecrosis. Int J Oral Maxillofac Surg. 2012 Nov;41(11):1422-6.

54 Rotaru H, Kim MK, Kim SG, Park YW. Pedicled buccal fat pad flap as a reliable surgical strategy for the treatment of medication-related osteonecrosis of the jaw. J Oral Maxillofac Surg. 2015 Mar;73(3):437-42.

55 Denes SA, Tieghi R, Elia G. The buccal fat pad for closure of oroantral communication. J Craniofac Surg. 2016 May;27(3):e327-30.

56 Duarte LF, Alonso K, Basso EC, Dib LL. Surgical treatment of bisphosphonate-related osteonecrosis of the jaws with the use of buccal fat pad: case report. Braz Dent J. 2015 May-Jun;26(3):317-20.

57 Berrone M, Florindi FU, Carbone V, Aldiano C, Pentenero M. Stage 3 Medication-Related Osteonecrosis of the Posterior Maxilla: Surgical Treatment Using a Pedicled Buccal Fat Pad Flap: Case Reports. J Oral Maxillofac Surg. 2015 Nov;73(11):2082-6.

58 Gallego L, Junquera L, Pelaz A, Hernando J, Megías J. The use of pedicled buccal fat pad combined with sequestrectomy in bisphosphonate-related osteonecrosis of the maxilla. Med Oral Patol Oral Cir Bucal. 2012 Mar; 17(2):e236-41.

59 Toshihiro Y, Nariai Y, Takamura Y, Yoshimura H, Tobita T, Yoshino A, et al. Applicability of buccal fat pad grafting for oral reconstruction. Int J Oral Maxillofac Surg. 2013 May;42(5):604-10.

60 Liu YM, Chen GF, Yan JL, et al. Functional reconstruction of maxilla with BFP, prefabricated titanium mesh and autologous bone grafts. Int J Oral Maxillofac Surg. 2006;35:1108. 
61 Fujimura N, Nagura H, Enomoto S. Grafting of the buccal fat pad into palatal defects. J Craniomaxillofac Surg. 1990 Jul;18(5):219-22.

62 Colella G, Tartaro G, Giudice A. The buccal fat pad in oral reconstruction. Br J Plast Surg. 2004 Jun;57(4):326-9.

63 Zhong LP, Chen GF, Fan LJ, Zhao SF. Immediate reconstruction of maxilla with bone grafts supported by pedicled buccal fat pad graft. Oral Surg Oral Med Oral Pathol Oral Radiol Endod. 2004 Feb;97(2):147-54.

64 Hao SP. Reconstruction of oral defects with the pedicled buccal fat pad flap. Otolaryngol Head Neck Surg. 2000 Jun;122(6):863-7.

65 Vuillemin T, Raveh J, Ramon Y. Reconstruction of the maxilla with bone grafts supported by the buccal fat pad. J Oral Maxillofac Surg. 1988 Feb;46(2):100-6.

66 Chien CY, Hwang CF, Chuang HC, Jeng SF, Su CY. Comparison of radial forearm free flap, pedicled buccal fat pad flap and split-thickness skin graft in reconstruction of buccal mucosal defect. Oral Oncol. 2005 Aug;41(7): 694-7.

67 Amin MA, Bailey BM, Swinson B, Witherow H. Use of the buccal fat pad in the reconstruction and prosthetic rehabilitation of oncological maxillary defects. Br J Oral Maxillofac Surg. 2005 Apr;43(2):148-54.

68 Chakrabarti J, Tekriwal R, Ganguli A, Ghosh S, Mishra PK. Pedicled buccal fat pad flap for intraoral malignant defects: A series of 29 cases. Indian J Plast Surg. 2009 Jan-Jun;42(1):36-42.

69 Hai HK. Repair of palatal defects with unlined buccal fat pad grafts. Oral Surg Oral Med Oral Pathol. 1988 May; 65(5):523-5.

70 Ho KH. Excision of cheek leukoplakia and lining the defect with a pedicle buccal fat pad graft. Br Dent J. 1989 Jun;166(12):455-6.

71 Dubin B, Jackson IT, Halim A, Triplett WW, Ferreira M. Anatomy of the buccal fat pad and its clinical significance. Plast Reconstr Surg. 1989 Feb;83(2):257-64.

72 Loh FC, Loh HS. Use of the buccal fat pad for correction of intramural defects: report of cases. J Oral Maxillofac Surg. 1992;20:193.

73 Bither S, Halli R, Kini Y. Buccal fat pad in intraoral defect reconstruction. J Maxillofac Oral Surg. 2013 Dec; 12(4):451-5.

74 Zhang Y, Zhao X, Fu S, Wu Y. Clinical application of the pedicle buccal fat pad flap in immediate reconstruction of oral tissue defect in oral surgery. J Craniofac Surg. 2017 Sep;28(6):1531-3.

75 Ye W, Song Y, Ying B, Hu J, Zhang C, Zhang Z. Use of the buccal fat pad in the immediate reconstruction of palatal defects related to cancer surgery with postoperative radiation therapy. J Oral Maxillofac Surg. 2014 Dec; 72(12):2613-20.

76 Mehrotra D, Pradhan R, Gupta S. Retrospective comparison of surgical treatment modalities in 100 patients with oral submucous fibrosis. Oral Surg Oral Med Oral Pathol Oral Radiol Endod. 2009 Mar;107(3):e1-10.

77 Sharma R, Thapliyal GK, Sinha R, Menon PS. Use of buccal fat pad for treatment of oral submucous fibrosis. J Oral Maxillofac Surg. 2012 Jan;70(1):228-32.

78 Rai A, Datarkar A, Rai M. Is buccal fat pad a better option than nasolabial flap for reconstruction of intraoral defects after surgical release of fibrous bands in patients with oral submucous fibrosis? A pilot study: a protocol for the management of oral submucous fibrosis. J Craniomaxillofac Surg. 2014 Jul;42(5):e111-6.

79 Lambade P, Dawane P, Thorat A. Efficacy of buccal fat pad in the surgical management of oral submucous fibrosis: a prospective study. Oral Maxillofac Surg. 2016 Jun;20(2):167-70.

80 Chao CK, Chang LC, Liu SY, Wang JJ. Histologic examination of pedicled buccal fat pad graft in oral submucous fibrosis. J Oral Maxillofac Surg. 2002 Oct;60(10):1131-4.

81 Yeh CJ. Application of the buccal fat pad to the surgical treatment of oral submucous fibrosis. Int J Oral Maxillofac Surg. 1996 Apr;25(2):130-3.

82 Wolford LM, Karras SC. Autologous fat transplantation around temporomandibular joint total joint prostheses: preliminary treatment outcomes. J Oral Maxillofac Surg. 1997 Mar;55(3):245-51.

83 Rattan V. A simple technique for use of buccal pad of fat in temporomandibular joint reconstruction. J Oral Maxillofac Surg. 2006 Sep;64(9):1447-51.

84 Bansal V, Bansal A, Mowar A, Gupta S. Ultrasonography for the volumetric analysis of the buccal fat pad as an interposition material for the management of ankylosis of the temporomandibular joint in adolescent patients. Br J Oral Maxillofac Surg. 2015 Nov;53(9):820-5.

85 Singh V, Dhingra R, Sharma B, Bhagol A, Kumar P. Retrospective analysis of use of buccal fat pad as an interpositional graft in temporomandibular joint ankylosis: preliminary study. J Oral Maxillofac Surg. 2011 Oct; 69(10):2530-6.

86 Singh V, Dhingra R, Bhagol A. Prospective analysis of temporomandibular joint reconstruction in ankylosis with sternoclavicular graft and buccal fat pad lining. J Oral Maxillofac Surg. 2012 Apr;70 (4):997-1006.

87 Gaba S, Sharma RK, Rattan V, Khandelwal N. The long-term fate of pedicled buccal pad fat used for interpositional arthroplasty in TMJ ankylosis. J Plast Reconstr Aesthet Surg. 2012 Nov;65(11):1468-73.

88 Mercuri LG, Ali FA, Woolson R. Outcomes of total alloplastic replacement with periarticular autogenous fat grafting for management of reankylosis of the temporomandibular joint. J Oral Maxillofac Surg. 2008 Sep; 66(9):1794-803.

89 Rubio-Bueno P, Ardanza B, Piñas L, Murillo N. Pedicled buccal fat pad flap for upper lip augmentation in orthognathic surgery patients. J Oral Maxillofac Surg. 2013 Apr;71(4):e178-84.

90 Cherekaev VA, Golbin DA, Belov AI. Translocated pedicled buccal fat pad: closure of anterior and middle skull base defects after tumor resection. J Craniofac Surg. 2012 Jan;23(1):98-104. 
Mannelli et al.: Indications and Outcomes

91 Kim JT, Naidu S, Kim YH. The buccal fat: a convenient and effective autologous option to prevent Frey syndrome and for facial contouring following parotidectomy. Plast Reconstr Surg. 2010 Jun;125(6):1706-9.

92 Torretta S, Pignataro L, Capaccio P, Brevi A, Mazzola R. The buccal fat: a convenient and effective autologous option to prevent Frey syndrome and for facial contouring following parotidectomy. Plast Reconstr Surg. 2011 Feb;127(2):998.

93 Kim YK, Yun PY, Oh JS, Kim SG. Prognosis of closure of large sinus membrane perforations using pedicled buccal fat pads and a resorbable collagen membrane: case series study. J Korean Assoc Oral Maxillofac Surg. 2014 Aug;40(4):188-94.

94 Hassani A, Khojasteh A, Alikhasi M, Vaziri H. Measurement of volume changes of sinus floor augmentation covered with buccal fat pad: a case series study. Oral Surg Oral Med Oral Pathol Oral Radiol Endod. 2009 Mar; 107(3):369-74.

95 Tamura E, Fukuda H, Tabata Y, Nishimura M. Use of the buccal fat [corrected] pad for vocal cord augmentation. Acta Otolaryngol. 2008 Feb;128(2):219-24.

96 Herring SM. Reconstruction of facial contour deformity with the buccal fat pad flap. Ann Plast Surg. 1992 Nov; 29(5):450-3.

97 Rattan V, Rai S, Vaiphei K. Use of buccal pad of fat to prevent heterotopic bone formation after excision of myositis ossificans of medial pterygoid muscle. J Oral Maxillofac Surg. 2008 Jul;66(7):1518-22.

98 Neder A. Use of buccal fat pad for grafts. Oral Surg Oral Med Oral Pathol. 1983 Apr;55(4):349-50.

99 Licameli GR, Dolan R. Buccinator musculomucosal flap. Arch Otolaryngol Head Neck Surg. 1998;124(1):69.

100 Pribaz J, Stephens W, Crespo L, Gifford G. A new intraoral flap: facial artery musculomucosal (FAMM) flap. Plast Reconstr Surg. 1992 Sep;90(3):421-9.

101 Salehi-Nik N, Rezai Rad M, Kheiri L, Nazeman P, Nadjmi N, Khojasteh A. Buccal Fat Pad as a Potential Source of Stem Cells for Bone Regeneration: A Literature Review. Stem Cells Int. 2017;2017:8354640. 